Article

\title{
Farmer Heterogeneity and Land Transfer Decisions Based on the Dual Perspectives of Economic Endowment and Land Endowment
}

\author{
Ying Cheng ${ }^{1,2,+} \mathbb{D}$, Yuan Hu ${ }^{1,2,3,+}$, Weizhong Zeng ${ }^{1,2, *}$ and Zhongbao Liu ${ }^{1,2}$ \\ 1 Western Rural Revitalization Research Center, College of Economics, Sichuan Agricultural University, \\ Chengdu 611130, China; 2019108001@stu.sicau.edu.cn (Y.C.); 2021108001@stu.sicau.edu.cn (Z.L.); \\ huyuan@sicau.edu.cn (Y.H.) \\ 2 College of Economics, Sichuan Agricultural University, Chengdu 611130, China \\ 3 Leibniz Institute of Agricultural Development in Transition Economies (IAMO), 06120 Halle (Saale), Germany \\ * Correspondence: auldkgk@sicau.edu.cn \\ + These authors contributed equally to this work and should be regarded as co-first authors.
}

Citation: Cheng, Y.; Hu, Y.; Zeng, W.; Liu, Z. Farmer Heterogeneity and Land Transfer Decisions Based on the Dual Perspectives of Economic Endowment and Land Endowment. Land 2022, 11, 353. https://doi.org/ 10.3390/land11030353

Academic Editors: Le Zhang and Yasuyuki Kono

Received: 8 February 2022

Accepted: 25 February 2022

Published: 27 February 2022

Publisher's Note: MDPI stays neutral with regard to jurisdictional claims in published maps and institutional affiliations.

Copyright: (C) 2022 by the authors. Licensee MDPI, Basel, Switzerland. This article is an open access article distributed under the terms and conditions of the Creative Commons Attribution (CC BY) license (https:// creativecommons.org/licenses/by/ $4.0 /)$.

\begin{abstract}
Guiding qualified farmers to transfer their land is an important way to alleviate the problem of land abandonment, improve land use efficiency, and achieve moderately large-scale land management. Based on the dual perspectives of economic endowment and land endowment, this paper uses the 2015 data of the China Household Finance Survey (CHFS), using the semilogarithmic ordinary least-squares method and the logit model, to explore differences in land transfer decisions under the effect of farmer heterogeneity. The circulation trading market was further improved to provide a reference. The heterogeneity of economic endowment and land endowment significantly affects the decision-making behavior of farmers in transferring land. The higher the land endowment is, the greater the probability that farmers transfer the land out and successfully trade, and they are more inclined to transfer the cultivated land to cooperatives, village collectives, and other institutions through formal channels, leading to a higher unit income of the transfer. Further research shows that land endowment has no significant difference in the impact of land endowment on whether farmers with different livelihood endowments transfer their land, but under the same land endowment, farmers with economic endowment advantages are more able to use their own endowment advantages to transfer their land out through formal channels and obtain higher gains income. Therefore, focusing on improving the conditions of land resources and increasing the endowment of farmers are important means to promote successful transactions in the land transfer market, ensure its sustainable operation, and promote further increase in the income of transfer farmers.
\end{abstract}

Keywords: land endowment; economic endowment; farmer heterogeneity; land transfer out

\section{Introduction}

The extensive operation of traditional agriculture causes an increasing proportion of the rural population to move to neighboring towns or cities, which leads to an increase in the land abandonment rate year by year in rural areas, especially in remote mountainous areas or backward areas [1,2]. Land circulation can effectively alleviate the problem of land abandonment, increase efficiency of land use and ecological security, optimize the distribution of elements, marginal output level, and income poverty reduction triple effect [3-6], and realize land scale management, solving food security and quality control problems in developing countries [7]. For instance, Brauw et al. [8] reported that land transfer improves the mobility of Ethiopian farming households, thus increasing their incomes. Jin et al. [9] testified that land transfer rents are important for poor people in developing countries such as Vietnam. Peng et al. [7] reported that land transfer can increase farmers' income and enhance their pension security. 
China is one of the largest developing countries in the world [10]. Collective land property rights are the basic system in rural China. Farmers have land contract rights, management rights, and the core of land transfer is the transfer of management rights. As early as 2004, the State Council of China issued the Decision on Deepening Reform and Strict Land Management, stipulating that the right to use construction land collectively owned by farmers can be transferred in accordance with the law. In 2014, the Chinese government issued the Opinions on Guiding the Orderly Transfer of Rural Land Management Rights and Developing Moderate Scale Agricultural Operations, calling for the development of land transfer. However, the development of land scale operations based on land circulation is not expected to go smoothly [11,12]. According to China's Rural Fixed Observation Points, the proportion of land transfer in the country as a whole rose from $17.1 \%$ in 2003 to $24 \%$ in 2013 , an increase of less than $7 \%$. In 2013 , only six provinces saw more than $30 \%$ of land transfer [13]. Moreover, in recent years, China's land transfer has been "Involution", and the growth rate of land transfer has fallen year by year. For example, from 2014 to 2017, the year-on-year growth rates of the land transfer area were 18.3, 10.8, 7.2, and 6.9\%, respectively. It is worth pondering why $61 \%$ of land remained un-transferred by the end of 2018, against the backdrop of a gradually improving land transfer market and more widespread nonfarming employment [14]. Therefore, it is significant to clarify the preconditions of successful land transfer transactions.

Theoretically, a farmer's resource endowment significantly impacts the farmer's transfer decision, and the transfer decision of different resource endowments is also disparate. In terms of studies on heterogeneous peasant households in land transfer, previous scholars usually differentiated peasant households according to part-time employment, working experience, income level, social security, and geographic feature and discussed the different transfer decisions of heterogeneous peasant households [15-17]. However, in addition to the above dimensions, the natural geographical conditions of land itself are also important factors that cannot be ignored in decision making regarding peasant household transfer $[18,19]$. In recent years, some scholars have gradually focused on the impact of natural endowments such as land area, slope, and degree of fragmentation on land transfer [20,21], but they are all based on small sample survey data in local areas, and the conclusions are weak in extrapolation.

Therefore, this paper uses land endowment and economic endowment to distinguish heterogeneous farmers. On the one hand, good land endowment and economic endowment can not only improve the price competitiveness of transfer-out farmers in the land transfer market and obtain higher transfer-out returns but also stimulate the transfer-out willingness of farmers or organizations pursuing high land return rates and promote the successful transaction of land transfer [22,23]. On the other hand, land endowment is an important factor and often ignored by researchers in the decision-making model of farmers' withdrawal from agricultural production. Then, how do different land endowments and economic endowments promote the "rational economic" farmer's agricultural production withdrawal (land transfer) decision change? So far, few studies have discussed this, and this paper attempts to answer this.

Compared with previous studies, the marginal contributions of this article are as follows: first, on the basis of a large sample of microdata (2015 Chinese Household Financial Survey data), this paper is used to assess the effect of heterogeneous farmers on land transfer decisions from a horizontal comparison perspective, which expands the analysis of the heterogeneous farmers and expands the framework of factors influencing farmers' land transfer decisions. Second, the land transfer decision is subdivided into whether to transfer out, the object of transfer, and the benefits of transfer and the differences in the transfer behavior of farmers with different land endowment and different economic endowment are compared and analyzed. On the basis of the above analysis, this paper responds to problems of land transfer path selection in theory and provides policy reference for further promoting effective land transfer and successful land transaction in practice. 


\section{Theoretical Analysis}

\subsection{Impact of Land Endowment on Land Transfer}

As the supplier of the land transfer market, whether farmers transfer their land depends on their judgment of the expected value of land. On the one hand, with the gradual increase in labor costs, the expected income of farmers in agricultural operation activities is low, which leads to the increasingly prominent problem of land abandonment in rural areas [18,24]. On the other hand, as the proportion of nonagricultural employment increases, a large number of young and middle-aged rural workers migrate to cities, increasing the opportunity cost of traditional smallholder productions.

It should be noted that according to prospect theory, under the hypothesis of the "rational economic person", farmers tend to transfer their land to obtain rental income in order to actively deal with the problems of land abandonment and high opportunity cost. However, a land transfer transaction requires the agreement of supply and demand. For the demand side, the land transfer decision is usually determined by the land operation scale under the maximization of net income, and the land transfer party needs to conduct cost-benefit analysis before deciding, that is, the net income of the land transfer must be greater than zero. Poor land endowment increases the agricultural operation cost of pesticides, fertilizers, machinery, and other aspects of the land transfer party, which may result in negative net income of the land transfer party [25]. Therefore, land with better land endowment has a higher probability of success in land transfer transactions. In order to avoid idled or abandoned land, farmers in China tend to transfer land to relatives, friends, and other acquaintances through informal channels, and implicit "human feeling" rent replaces explicit monetary rent. Studies showed that the rental income of individuals is significantly lower than that of enterprises and village collective organizations [26].

Accordingly, this paper proposes Hypothesis 1: land endowment has a significant positive impact on farmers' land transfer decisions, and the better the land endowment is, the more inclined farmers are to transfer it to organizations through formal channels to obtain higher rental income.

\subsection{Analysis of Economic Endowment on Land Transfer}

The economic endowment of different peasant households is not the same, and there even are great distinctions. Under the constraints of livelihood capital such as economic income, social capital, and family labor structure, the choice of livelihood strategies of households is also subject to many restrictions. Compared with high-income families, low-income families have a single source of income and are mainly agricultural, so they rely more on land for livelihood and are less likely to transfer farmland out. In addition, due to the relatively weak social capital endowment of low-income families, they lack the right to speak in land transfer transactions and eventually become passive recipients of prices. Therefore, low-income families often obtain low rental income through land transfer. Accordingly, this paper proposes Hypothesis 2: economic endowment has a significant positive impact on farmers' land transfer decisions, and the better the economic endowment is, the more inclined farmers are to transfer it to organizations through formal channels to obtain higher rental income.

In conclusion, the theoretical analysis framework of this paper is shown in Figure 1. 


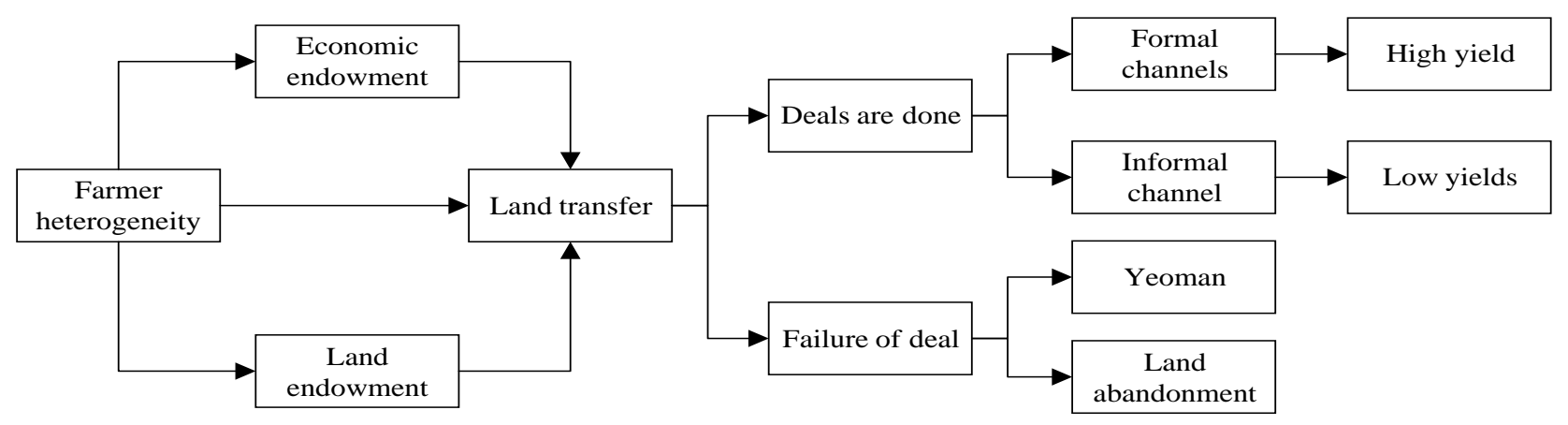

Figure 1. Theoretical analysis of household heterogeneity affecting land transfer.

\section{Empirical Approach, Data Source, Variable Definition}

\subsection{Method}

This study mainly includes two parts: (1) The impact of household heterogeneity on the land transfer decision and transfer object. As the dependent variable is dichotomous, OLS regression is not suitable. Therefore, the logit model was used for empirical estimation in this paper. (2) The impact of household heterogeneity on land transfer rents. Since the circulation rent was positive, considering the requirement of normal distribution, a semilogarithmic OLS model was selected in this paper. For probing interactions of linear models, simplify the computations and facilitate the probing of interactions in ordinary least squares and logistic regression [27]. The basic model was set as shown in Equation (1):

$$
\text { Land }=\beta_{0}+\beta_{1} \text { Farmer }+\beta_{2} \text { Control }+\mu
$$

where the explained variable Land represents the land transfer out, including the land transfer out, the transfer object, and the transfer income of the three related variables; Farmer denotes household heterogeneity, which is the core explanatory variable of this paper, including heterogeneity of land endowment and economic endowment, Control represents the set of factors influencing the land transfer of households, and $\mu$ is the error term that follows normal distribution.

\subsection{Data Source}

The Chinese Household Finance Survey (CHFS) conducted by the Survey and Research Center for China Household Finance of Southwestern University of Finance and Economics is a very representative microdata base in China. It conducted a survey on land endowment in 2015 but cancelled relevant indicators in the new survey round in 2017. Therefore, we selected the cross-sectional data of CHFS in 2015 as the research sample of this paper.

The total sample of CHFS data for 2015 comprised 37,341 sample households in 29 provinces (excluding Xinjiang and Tibet), 353 counties, and 1373 communities or villages, which was based on modern hierarchical, multi-stage, and scale sampling (PPS) techniques and a computer-aided survey system (CAPI) [28]. The rural sample included 11,635 households, accounting for $31.2 \%$. Considering that this paper focuses on the impact of land endowment on land transfer, a sample of 15,542 land-owning households (including 2732 land-transferring households) were screened, covering 29 provinces in China, composed of 6116 households in eastern China, 4842 households in central China, and 4584 households in western China.

This paper only considers land transfer because land endowment has strong externality, and the empirical estimation model is less likely to have endogeneity problems, so the estimation result is more accurate. If land transfer is considered, it is difficult to solve potential endogenous problems on the basis of existing data and methods. To be specific, farmers may carry out a series of intervention activities after transferring to the land, such as land leveling, building mechanical and tillage roads, power supply, drainage, irrigation, and other facilities, thus affecting the land endowment. Such endogeneity problems caused 
by reverse causality cannot satisfy the assumptions of the empirical model (that is, the independent variables are exogenous variables) and eventually lead to inaccurate empirical estimation results. In addition, there are no relevant indicators indicating the quality of land before and after transfer in the existing data, so it is impossible to obtain the relevant data of land endowment before transfer. Therefore, the final choice only considers the land transfer behavior.

\subsection{Variable Definition \\ 3.3.1. Explained Variables}

This paper adopted three types of indicators to measure the land outflow situation of peasant households. The first is the land transfer decision, which refers to whether households transfer the management right of land to others or institutions, as a binary variable. The second is the objects of land transfer. In the original questionnaire, the objects of land transfer mainly included eight categories, which were divided into private (informal channels) and institutional (formal channels) according to the research needs of this paper, which are also binary variables. The third is the unit income of land transfer, which can be obtained by dividing the land transfer income (CNY) by the land transfer area (mu). In order to further satisfy the normal distribution hypothesis, we take logarithmic processing.

\subsubsection{Explanatory Variables}

Land endowment and economic endowment are the core explanatory variables in this paper. The indexes used in existing studies to measure land endowment mainly focus on natural conditions such as land area and fertility $[29,30]$, which basically belong to objective conditions. However, land transfer is a behavioral decision of farmers and also affected by subjective factors. We consider both subjective and objective dimensions to measure land endowment. Specifically, the subjective scoring method commonly used in subjective land endowment research is used for reference [31,32]. Farmers' subjective evaluation of land was used to measure the land, and the range from 1 to 5 was very poor, poor, average, good, and very good. For objective land endowment, referring to the previous studies [33-35], in this paper, the six binary indicators of suitability for largescale mechanical farming, proximity to mechanical farming roads, irrigation facilities, power supply facilities, drainage facilities, and contaminated condition were selected to obtain the comprehensive index of objective land endowment by summarizing and adding them. The larger the value is, the better the land endowment is. Economic endowment is measured by the relative level of village average income; higher than the village average is classified as high-income families, and lower than the village average is classified as low-income families.

\subsubsection{Control Variables}

To reduce the impact of missing variables on the research results, this paper referred to existing literature to determine the control variables to be used [36-38], mainly comprised three levels: householder characteristics, family characteristics, and community $[39,40]$. In terms of the characteristics of household heads, the gender, age, and education level are three important factors affecting the land transfer [41,42]. Generally speaking, the difference of risk preference and value expectation between male and female householders will affect the decision of land transfer. With the increase in the age of household heads, their labor capacity becomes weaker, and it is difficult to independently engage in largescale agricultural operations, so they are more inclined to transfer land out to obtain rental income [43]. In addition, the higher the education level of farmers is, the higher the probability of nonagricultural employment, the less dependent they are on land for livelihood, so the more inclined they are to transfer land. At the level of family characteristics, relevant studies show that the structure of family members and employment are factors affecting land transfer market transactions. Therefore, this paper adopted four indicators to reflect the basic situation of families: family size, average education level (total education level of 
all family members / family size), average health (total health condition of all family members/family size), and nonagricultural employment ratio [44,45]. At the community level, village topographic features are controlled [46]. Table 1 shows the selection, definitions, and assignment of all variables for the empirical model.

Table 1. Variable selection, definition, and assignment.

\begin{tabular}{|c|c|c|}
\hline Variable Classes & Variable Name & Variable Meaning and Assignment \\
\hline \multirow{3}{*}{ Explained variables } & Land transfer decision & $\begin{array}{l}\text { Whether to transfer the land management right to others or } \\
\text { organizations: } 1=\text { yes; } 0=\text { no }\end{array}$ \\
\hline & Land transfer objects & $\begin{array}{c}1=\text { private (ordinary farmers of the village, ordinary farmers of the } \\
\text { other village, professional large households, family farms); } \\
0=\text { institutions (farmer cooperatives, village collectives, companies } \\
\text { or enterprises, intermediary agencies) }\end{array}$ \\
\hline & Land transfer income & Land transfer income/land transfer area, $\mathrm{CNY} / \mathrm{mu}$ \\
\hline \multirow{8}{*}{ Explanatory variables } & $\begin{array}{l}\text { Subjective evaluation of } \\
\text { land endowment }\end{array}$ & $1=$ very poor $; 2=$ poor $3=$ average $4=$ good $; 5=$ very good \\
\hline & \multirow{6}{*}{$\begin{array}{l}\text { Objective evaluation of } \\
\text { land endowment }\end{array}$} & Whether it is suitable for large mechanical farming: $1=$ yes; $0=$ no \\
\hline & & Is it close to the mechanical farming roads? $1=$ yes; $0=$ no \\
\hline & & Whether irrigation facilities are available: $1=$ yes; $0=$ no \\
\hline & & Whether there is power supply: $1=$ yes; $0=$ no \\
\hline & & Whether drainage facilities are available: $1=$ yes; $0=$ no \\
\hline & & Is it contaminated? $1=$ no; $0=$ yes \\
\hline & Economic endowment & $\begin{array}{l}\text { Higher than the average income level of the village = high-income } \\
\text { families; otherwise, low-income families }\end{array}$ \\
\hline \multirow{8}{*}{ Control variables } & Gender of head of household & $1=$ male $; 2$ female \\
\hline & Age of head of household & Years \\
\hline & $\begin{array}{l}\text { Educational level of head } \\
\text { of household }\end{array}$ & $\begin{array}{c}1=\text { illiterate; } 2=\text { elementary school; } 3=\text { junior middle school; } 4=\text { high } \\
\text { school; } 5=\text { technical secondary } / \text { vocational high school; } 6=\text { junior } \\
\text { college } / \text { higher vocational college; } 7=\text { bachelor's degree; } 8=\text { master's } \\
\text { degree; } 9=\mathrm{PhD} \text { students }\end{array}$ \\
\hline & Family size & Number of family members, people \\
\hline & Family educational level & $\begin{array}{c}1=\text { illiterate; } 2=\text { elementary school; } 3=\text { junior middle school; } 4=\text { high } \\
\text { school; } 5=\text { technical secondary } / \text { vocational high school; } 6=\text { junior } \\
\text { college } / \text { higher vocational college; } 7=\text { bachelor's degree; } 8=\text { master's } \\
\text { degree; } 9=\text { PhD students }\end{array}$ \\
\hline & Family health condition & $1=$ very bad $; 2=$ bad $3=$ average $; 4=$ good $; 5=$ very good \\
\hline & $\begin{array}{l}\text { Nonagricultural } \\
\text { employment ratio }\end{array}$ & Non-farm payrolls/family size, $\%$ \\
\hline & Village terrain & $1=$ hills or mountains $; 0=$ plains \\
\hline
\end{tabular}

\section{Results}

\subsection{Descriptive Results}

Table 2 shows the results of the descriptive statistical analysis of the relevant variables. Results show the following:

(1) The land transfer rate and unit income of low-income families were lower than those of high-income families. The land transfer rate of peasant households was about $18 \%$, among which $89 \%$ of peasant households chose to transfer their land to private individuals through informal channels, with an average transfer income of CNY 713.61 per $\mathrm{mu}$ of land. Specifically, the land transfer rate of low-income families was about $13 \%$, and that of high-income families was $18 \%$. The land transfer rate of 
low-income families was thus about $5 \%$ lower than that of high-income families. In terms of the transfer objects, there is little difference between low- and high-income families. The per mu income of land transfer for low-income families was CNY 385.77, significantly lower than CNY 742.90 for high-income families.

(2) The land endowment of low-income households was significantly worse than that of high-income households. The average subjective land endowment level of all sampled households was between average and good, which was 3.35. In terms of the objective land endowment, the average of the whole sample of peasant households reached the standard of three out of six indicators. Specifically, the average subjective evaluation of land endowment of low-income families was 3.21, slightly lower than that of high-income families, 3.37. The objective evaluation of land endowment of lowincome families is indeed lower than that of high-income families, with an average of 2.75 items reaching the standard, lower than the 3.08 items of high-income families.

(3) The heads of peasant households are mostly middle-aged and elderly, and educational level is generally low. The average age of the household head of the whole sample was 52.35 years old, and most of them had primary or junior high school education. Specifically, the average age of heads from low- and high-income families was 55.87 and 51.92 years old, that is, the average age of heads from low-income families was higher than that from high-income families. The average educational level of the heads of low-income households was 2.25, lower than the 2.75 of high-income households.

(4) There were significant differences between low- and high-income households in average levels of education, health status, and share of nonfarm employment. The average number of household members in the full sample was about four, the average level of education was between primary and secondary school, the average health status was between bad and fair, and more than two-thirds of the household members on average worked off-farm. Specifically, there was no significant difference in the number of members between low- and high-income families. The average educational level and health status of members of low-income families are lower than those of highincome families. The share of family members in nonfarming employment was $65 \%$ for low-income households on average, $6 \%$ lower than that for high-income households.

Table 2. Descriptive statistics.

\begin{tabular}{|c|c|c|c|c|c|c|c|}
\hline \multirow[b]{2}{*}{ Index } & \multicolumn{2}{|c|}{ All Samples } & \multicolumn{2}{|c|}{ Low-Income Families } & \multicolumn{2}{|c|}{ High-Income Families } & \multirow[b]{2}{*}{ Units } \\
\hline & Mean & $\begin{array}{l}\text { Standard } \\
\text { Deviation }\end{array}$ & Mean & $\begin{array}{l}\text { Standard } \\
\text { Deviation }\end{array}$ & Mean & $\begin{array}{l}\text { Standard } \\
\text { Deviation }\end{array}$ & \\
\hline Land transfer decision & 0.18 & 0.38 & 0.13 & 0.34 & 0.18 & 0.39 & - \\
\hline Land transfer objects & 0.89 & 0.31 & 0.88 & 0.33 & 0.90 & 0.31 & - \\
\hline Land transfer income & 713.61 & 4750.25 & 385.77 & 1379.59 & 742.90 & 4939.77 & $\mathrm{CNY} / \mathrm{mu}$ \\
\hline Subjective evaluation of land endowment & 3.35 & 0.99 & 3.21 & 1.03 & 3.37 & 0.99 & - \\
\hline Objective evaluation of land endowment & 3.04 & 1.64 & 2.75 & 1.59 & 3.08 & 1.64 & - \\
\hline Gender of head of household & 1.14 & 0.34 & 1.13 & 0.34 & 1.14 & 0.35 & - \\
\hline Age of head of household & 52.35 & 12.91 & 55.87 & 13.07 & 51.92 & 12.83 & Year \\
\hline Educational level of head of household & 2.70 & 1.15 & 2.25 & 0.9 & 2.75 & 1.17 & - \\
\hline Family size & 4.07 & 1.84 & 4.06 & 2.02 & 4.07 & 1.82 & Person \\
\hline Family education level & 2.43 & 1.01 & 2.04 & 0.83 & 2.48 & 1.02 & - \\
\hline Family health condition & 2.18 & 0.88 & 2.51 & 0.95 & 2.14 & 0.86 & - \\
\hline Nonagricultural employment ratio & 0.71 & 0.32 & 0.65 & 0.32 & 0.71 & 0.32 & $\%$ \\
\hline Village terrain & 0.42 & 0.13 & 0.45 & 0.13 & 0.41 & 0.11 & - \\
\hline
\end{tabular}

\subsection{Empirical Results}

4.2.1. Influence of Land Endowment on Land Transfer

Table 3 presents the empirical estimates. 
Table 3. Impact analysis of land transfer.

\begin{tabular}{|c|c|c|c|c|c|c|}
\hline Index & $\begin{array}{l}\text { Model (1) } \\
\text { Whether to } \\
\text { Transfer }\end{array}$ & $\begin{array}{l}\text { Model (2) } \\
\text { Transfer } \\
\text { Objects }\end{array}$ & $\begin{array}{l}\text { Model (3) } \\
\text { Transfer } \\
\text { Income }\end{array}$ & $\begin{array}{l}\text { Model (4) } \\
\text { Whether to } \\
\text { Transfer }\end{array}$ & $\begin{array}{l}\text { Model (5) } \\
\text { Transfer } \\
\text { Objects }\end{array}$ & $\begin{array}{c}\text { Model (6) } \\
\text { Transfer } \\
\text { Income }\end{array}$ \\
\hline Subjective land endowment & $\begin{array}{c}0.228^{* * *} \\
(9.90)\end{array}$ & $\begin{array}{l}-0.126^{*} \\
(-1.90)\end{array}$ & $\begin{array}{c}0.433^{* * *} \\
(7.48)\end{array}$ & & & \\
\hline Objective land endowment & & & & $\begin{array}{c}0.194^{* * *} \\
(14.52)\end{array}$ & $\begin{array}{c}-0.085^{* *} \\
(-2.17)\end{array}$ & $\begin{array}{c}0.503^{* * *} \\
(14.83)\end{array}$ \\
\hline Economic endowment & $\begin{array}{c}0.272 * * * \\
(3.38)\end{array}$ & $\begin{array}{l}0.197 \\
(0.87)\end{array}$ & $\begin{array}{l}0.238 \\
(1.15)\end{array}$ & $\begin{array}{c}0.249 * * * \\
(3.10)\end{array}$ & $\begin{array}{l}0.210 \\
(0.92)\end{array}$ & $\begin{array}{l}0.158 \\
(0.77)\end{array}$ \\
\hline \multicolumn{7}{|l|}{ Head characteristics } \\
\hline Gender & $\begin{array}{l}0.084 \\
(1.36)\end{array}$ & $\begin{array}{l}0.173 \\
(0.97)\end{array}$ & $\begin{array}{c}-0.515^{* * *} \\
(-3.31)\end{array}$ & $\begin{array}{c}0.108 \text { * } \\
(1.73)\end{array}$ & $\begin{array}{l}0.167 \\
(0.94)\end{array}$ & $\begin{array}{c}-0.440 \text { *** } \\
(-2.92)\end{array}$ \\
\hline Age & $\begin{array}{c}0.019 * * * \\
(9.79)\end{array}$ & $\begin{array}{l}0.008 \\
(1.59)\end{array}$ & $\begin{array}{l}-0.001 \\
(-0.30)\end{array}$ & $\begin{array}{c}0.019 * * * \\
(9.77)\end{array}$ & $\begin{array}{l}0.008 \\
(1.54)\end{array}$ & $\begin{array}{l}-0.001 \\
(-0.30)\end{array}$ \\
\hline Degree of education & $\begin{array}{l}0.030 \\
(1.19)\end{array}$ & $\begin{array}{l}0.056 \\
(0.83)\end{array}$ & $\begin{array}{l}-0.015 \\
(-0.23)\end{array}$ & $\begin{array}{l}0.031 \\
(1.22)\end{array}$ & $\begin{array}{l}0.052 \\
(0.77)\end{array}$ & $\begin{array}{l}-0.011 \\
(-0.17)\end{array}$ \\
\hline \multicolumn{7}{|l|}{ Family characteristics } \\
\hline Membership & $\begin{array}{c}-0.155^{* * *} \\
(-10.88)\end{array}$ & $\begin{array}{l}-0.054 \\
(-1.38)\end{array}$ & $\begin{array}{l}-0.035 \\
(-0.90)\end{array}$ & $\begin{array}{c}-0.157 * * * \\
(-10.91)\end{array}$ & $\begin{array}{l}-0.053 \\
(-1.36)\end{array}$ & $\begin{array}{l}-0.027 \\
(-0.72)\end{array}$ \\
\hline Average education level & $\begin{array}{c}0.049 * \\
(1.86)\end{array}$ & $\begin{array}{l}-0.071 \\
(-1.00)\end{array}$ & $\begin{array}{l}0.049 \\
(0.71)\end{array}$ & $\begin{array}{l}0.036 \\
(1.35)\end{array}$ & $\begin{array}{l}-0.066 \\
(-0.91)\end{array}$ & $\begin{array}{l}-0.001 \\
(-0.01)\end{array}$ \\
\hline Average health level & $\begin{array}{l}0.045 \\
(1.54)\end{array}$ & $\begin{array}{l}-0.000 \\
(-0.01)\end{array}$ & $\begin{array}{l}0.060 \\
(0.80)\end{array}$ & $\begin{array}{l}0.046 \\
(1.56)\end{array}$ & $\begin{array}{l}0.008 \\
(0.11)\end{array}$ & $\begin{array}{l}0.065 \\
(0.89)\end{array}$ \\
\hline Nonagricultural employment ratio & $\begin{array}{c}2.824^{* * *} \\
(25.21)\end{array}$ & $\begin{array}{c}0.914^{* * *} \\
(4.33)\end{array}$ & $\begin{array}{c}-0.984^{* * *} \\
(-4.30)\end{array}$ & $\begin{array}{c}2.874^{* * *} \\
(25.32)\end{array}$ & $\begin{array}{c}0.913^{* * *} \\
(4.33)\end{array}$ & $\begin{array}{c}-0.950 * * * \\
(-4.24)\end{array}$ \\
\hline \multicolumn{7}{|l|}{ Community characteristics } \\
\hline Village terrain & $\begin{array}{c}-0.174^{* * *} \\
(-15.38)\end{array}$ & $\begin{array}{l}-0.022 * \\
(-1.91)\end{array}$ & $\begin{array}{c}-0.127^{* * * *} \\
(-4.72)\end{array}$ & $\begin{array}{c}-0.181^{* * *} \\
(-17.09)\end{array}$ & $\begin{array}{c}-0.030 \text { ** } \\
(-2.32)\end{array}$ & $\begin{array}{c}-0.135 \text { *** } \\
(-5.17)\end{array}$ \\
\hline Constant & $\begin{array}{c}-5.281 * * * \\
(-23.66)\end{array}$ & $\begin{array}{c}1.433^{* *} \\
(2.35)\end{array}$ & $\begin{array}{c}3.772 * * * \\
(6.57)\end{array}$ & $\begin{array}{c}-5.158 * * * \\
(-24.14)\end{array}$ & $\begin{array}{c}1.273^{* *} \\
(2.23)\end{array}$ & $\begin{array}{c}3.522 * * * \\
(6.57)\end{array}$ \\
\hline Sample size & 15,542 & 2732 & 2732 & 15,542 & 2732 & 2732 \\
\hline
\end{tabular}

(1) The influence of land endowment on land transfer decision: Columns one and four of Table 3 report the impact of subjective and objective land endowment, respectively, on peasant households' land transfer decisions. In both the subjective and the objective dimension, land endowment improved the probability of land transfer decision at a significance level of $1 \%$, which verified Hypothesis 1 .

(2) The influence of land endowment on the object of land transfer: Columns two and five of Table 3 report the impact of subjective and objective land endowment, respectively, on the land transfer objects of peasant households. The results show that the higher the land endowment, the more likely the peasant households are to transfer their land to institutions through formal channels. The subjective and objective dimensions pass the test at a significance level of 10 and 5\%, respectively, verifying Hypothesis 1 .

(3) The influence of land endowment on land transfer income: Columns three and six of Table 3 report the impact of subjective and objective land endowment, respectively, on peasant households' income from land transfer. Estimation results show that land endowment increased the unit income of land transfer at a significance level of $1 \%$ in both subjective and objective dimensions, which verified Hypothesis 1.

\subsubsection{Influence of Economic Endowment on Land Transfer}

Table 3 reports the impact of economic endowment on land transfer. From the estimation results, economic endowment increased the decision-making probability of land 
transfer at a significance level of $1 \%$. However, the object and income of land transfer are not significant, so Hypothesis 2 is untenable.

In order to further analyze the difference of household heterogeneity affecting land transfer among households with different economic endowments, we conducted subsample regression according to the economic endowments, which also helped in verifying the robustness of the above regression results. Table 4 reports the impact of land endowment on the land transfer behavior of high- and low-income families. The results show that there was no significant difference in the impact of land endowment on the land transfer decision of the two types of farmers. According to the regression results in columns three and four, the impact of subjective land endowment on the objects of land transfer is still significant in the sample of high-income families but becomes insignificant in the sample of low-income families. Columns five and six are the estimated results of land endowment for the land transfer benefits of the two types of farmers. This is basically consistent with the regression results of the whole sample, but the coefficient of subjective land endowment affecting the land transfer income of low-income households was significantly lower than that of high-income households. This reflects that compared with high-income families, low-income families are often in a weak position of land transfer and eventually become passive recipients of the market price of land transfer, resulting in their unit rental income being significantly lower than high-income families.

Table 4. Subsample regression results.

\begin{tabular}{|c|c|c|c|c|c|c|}
\hline \multirow{3}{*}{ Index } & (1) & (2) & (3) & (4) & (5) & (6) \\
\hline & \multicolumn{2}{|c|}{ Whether to Turn Out } & \multicolumn{2}{|c|}{ Transfer Objects } & \multicolumn{2}{|c|}{ Transfer Income } \\
\hline & $\begin{array}{l}\text { Low-Income } \\
\text { Families }\end{array}$ & $\begin{array}{l}\text { High-Income } \\
\text { Families }\end{array}$ & $\begin{array}{l}\text { Low-Income } \\
\text { Families }\end{array}$ & $\begin{array}{l}\text { High-Income } \\
\text { Families }\end{array}$ & $\begin{array}{l}\text { Low-Income } \\
\text { Families }\end{array}$ & $\begin{array}{l}\text { High-Income } \\
\text { Families }\end{array}$ \\
\hline Subjective land endowment & $\begin{array}{c}0.226^{* * *} \\
(2.92)\end{array}$ & $\begin{array}{c}0.228^{* * *} \\
(9.46)\end{array}$ & $\begin{array}{l}-0.083 \\
(-0.41)\end{array}$ & $\begin{array}{l}-0.130 * \\
(-1.83)\end{array}$ & $\begin{array}{c}0.289 * \\
(1.67)\end{array}$ & $\begin{array}{c}0.448^{* * *} \\
(7.29)\end{array}$ \\
\hline Objective land endowment & $\begin{array}{c}0.199 * * * \\
(4.16)\end{array}$ & $\begin{array}{c}0.193^{* * *} \\
(13.85)\end{array}$ & $\begin{array}{l}0.077 \\
(0.55)\end{array}$ & $\begin{array}{l}-0.102 * * \\
(-2.51)\end{array}$ & $\begin{array}{c}0.314^{* * *} \\
(2.68)\end{array}$ & $\begin{array}{c}0.520 * * * \\
(14.69)\end{array}$ \\
\hline Control variable & Control & Control & Control & Control & Control & Control \\
\hline Sample size & 1692 & 13,850 & 224 & 2508 & 224 & 2508 \\
\hline
\end{tabular}

$* * *$, and ${ }^{* * *}$ represent significance at 10,5 , and $1 \%$ levels, respectively; numbers in brackets are $t$ values of robust estimates.

\section{Discussion}

In this study, a large sample size survey of 15,542 households was selected to study the impact of household heterogeneity on land transfer from the perspective of land endowment and economic endowment. This study not only focuses on the decision of land transfer, but also investigates the objects and income of land transfer, which is more comprehensive and practical. At the same time, this study further analyzed the difference of household heterogeneity affecting land transfer among households with different economic endowments and found that the results remained robust. As the largest developing country in the world, the research results of rural China have strong practical significance. They can provide references for other developing countries to realize large-scale land management.

The results of this study have some similarities and differences to previous studies. From the perspective of land transfer, land endowment significantly impacts the land transfer decision, especially when the head of a household is older and thus more inclined to transfer land. This result is consistent with the findings of He et al. [36], who argued that land transfer can liberate the rural elderly from the heavy burden of traditional farming [6]. More specifically, with the increase of age, the income of famers through farming gradually decreases, while the rent obtained from land transfer can bring them higher income. At the level of family characteristics, the higher the share of nonagricultural employment among family members, the greater the probability of land transfer. As Hoq et al. [47], Wang et al. [48], and Pfeiffer et al. [49] considered that the labor force mainly works in 
towns/urban areas and is more stable and of higher income than in rural areas, they are more willing to transfer land since they are less dependent on land. In terms of economic endowment, this is further supported by the fact that low-income families are less likely to transfer land than high-income families.

In terms of the land transfer objects, the higher the proportion of nonagricultural employment among household members is, the more inclined they are to transfer their land to private individuals through informal channels. There are two possible reasons: On the one hand, farmers with a higher proportion of nonagricultural employment are less dependent on land. In order to avoid idle and abandoned land, farmers tend to transfer land to relatives and friends through informal channels and use hidden "human rent" instead of "monetary rent" [50]. On the other hand, the lower the proportion of nonagricultural employment among household members is, the lower their social capital and smaller their acquaintance network are, so they are more likely to choose formal channels in land transfer transactions. Meanwhile, this is consistent with the fact described in a paper by Du et al. [51], that China's rural society is an "acquaintance society".

At the same time, the results of the present study were different from the findings of Cheng et al. [52], who founded the "male and female co-negotiation" land transfer model. Especially in terms of land transfer income, the gender of household heads showed that the unit income of female-headed households in land transfers was lower than that of male-headed households. This is because in most rural areas of China, female heads of households have weak negotiation abilities in land transfer transactions and generally become passive recipients of market prices. This is consistent with [53,54] and other studies, where female-headed households remain somewhat marginalized.

In addition, this study has several deficiencies that can be addressed in future studies, as follows: (1) We selected the cross-sectional data of CHFS in 2015 as the research sample of this paper. However, the influence of farmer heterogeneity on land transfer is a dynamic process. Thus, future research could use panel data to further expand and verify the relationship in greater detail. (2) Based on the empirical evidence from rural areas of China, this paper studies the relationship between farmer heterogeneity and land transfer, and whether this relationship is applicable to other countries or regions remains to be discussed.

\section{Conclusions and Implications}

On the basis of the survey data of the CHFS in 2015, OLS and the logit model were used to quantitatively study the differential influence of farmers' heterogeneity on land transfer decisions from the dual perspective of land endowment and economic endowment.

Generally speaking, the higher the land endowment is, the higher the probability of a land transfer and the successful transaction of farmers, the more inclined they are to transfer the land to institutions through formal channels, and the higher the unit income of the land transfer. There was no significant difference in the impact of land endowment on whether farmers with different economic endowments transfer land. However, under the same land endowment, compared with low-income families, high-income families can transfer land out through formal channels and obtain higher returns by virtue of their endowment advantages.

In addition to their theoretical significance, the results of the present study have definite policy implications. As noted earlier, the land endowment and land transfer have a strong positive correlation. Thus, the government should insist on the further construction of high-standard farmland (high-standard farmland aims at building infrastructures to improve farmland's productivity, such as roads, irrigation, power supply, and drainage). Through the moderate infrastructure construction above, the overall land endowment for families will be improved. However, at the same time, it is worth noticing that under the same land endowment, the land transfer income of low-income families is significantly lower than high-income families. Therefore, the government needs to be aware of the income between high- and low-income families in land transfers. So, building an official land transfer platform and providing land transfer services to guide low-income families 
correctly is a key issue to obtain an even rental income and improve the transactions' success rate.

Author Contributions: Conceptualization, Y.C., Y.H. and Z.L.; formal analysis, Y.H. and W.Z.; funding acquisition, W.Z.; methodology, Y.H.; visualization, Y.C. and Z.L.; writing —original draft, Y.C., Y.H. and Z.L.; writing-review and editing, Y.C., Y.H., W.Z. and Z.L. All authors have read and agreed to the published version of the manuscript.

Funding: This research was funded by the Social Science Foundation of Ministry of Education of China (grant no. 21YJA790002) and the Sichuan Province Soft Science Research Program (grant no. 22RKK0097).

\section{Institutional Review Board Statement: Not applicable.}

Informed Consent Statement: Informed consent was obtained from all subjects involved in the study.

Data Availability Statement: Restrictions apply to the availability of these data. Data were obtained from the Survey and Research Center for China Household Finance and are available from the Yuan $\mathrm{Hu}$ with the permission of the Survey and Research Center for China Household Finance.

Acknowledgments: All authors gratefully acknowledge the support from the Social Science Foundation of Ministry of Education of China (grant no. 21YJA790002) and the Sichuan Province Soft Science Research Program (grant no. 22RKK0097). We also extend our gratitude to the anonymous reviewers and editors for their helpful reviews and critical comments. Additionally, all authors are very grateful to the Chinese Household Finance Survey and Research Center of Southwestern University of Finance and Economics, who provided the data.

Conflicts of Interest: All authors declare no conflict of interest.

\section{References}

1. Li, S.; Li, X.; Xin, L.; Tan, M.H.; Wang, X.; Wang, R.J.; Jiang, M.; Wang, Y. Extent and distribution of cropland abandonment in Chinese mountainous areas. Resour. Sci. 2017, 10, 1801-1811. [CrossRef]

2. MacDonald, D.; Crabtree, J.R.; Wiesinger, G.; Dax, T.; Stamou, N.; Fleury, P.; Lazpita, J.G.; Gibon, A. Agricultural abandonment in mountain areas of Europe: Environmental consequences and policy response. J. Econ. Manag. 2000, 59, 47-69. [CrossRef]

3. Kung, K.S. Off-Farm Labor Markets and the Emergence of Land Rental Markets in Rural China. J. Comp. Econ. 2002, 30, 395-414. [CrossRef]

4. Qian, Z.; Yi, X. Current situation and policy improvement of agricultural land transfer in China-An analysis based on the survey data of Jiangsu, Guangxi, Hubei and Heilongjiang provinces. Manag. World 2016, 2, 71-81. (In Chinese) [CrossRef]

5. Lu, H.; Xie, H. Impact of changes in labor resources and transfers of land use rights on agricultural non-point source pollution in Jiangsu Province, China. J. Econ. Manag. 2018, 207, 134-140. [CrossRef]

6. Wang, Y.; Yang, Q.; Xin, L.; Zhang, J. Does the New Rural Pension System Promote Farmland Transfer in the Context of Aging in Rural China: Evidence from the CHARLS. Int. J. Environ. Res. Public Health 2019, 16, 3592. [CrossRef]

7. Deng, X.; Xu, D.; Zeng, M.; Qi, Y. Does early-life famine experience impact rural land transfer? Evidence from China. Land Use Policy 2019, 81, 58-67. [CrossRef]

8. Brauw, A.D.; Mueller, V. Do Limitations in Land Rights Transferability Influence Mobility Rates in Ethiopia? J. Afr. Econ. 2012, 21, 548-579. [CrossRef]

9. Jin, S.; Deininger, K. Land Sales and Rental Markets in Transition: Evidence from Rural Vietnam. Oxf. Bull. Econ. Stat. 2010, 70, 67-101. [CrossRef]

10. Peng, K.; Yang, C.; Chen, Y.D. Land transfer in rural China: Incentives, influencing factors and income effects. Appl. Econ. 2020, 52, 5477-5490. [CrossRef]

11. Wang, Y.H.; Li, X.; Xin, L.; Tan, M.H.; Jiang, M. Regional differences of land circulation in China and its drivers: Based on 2003-2013 rural fixed observation points data. Acta Geogr. Sin. 2018, 73, 487-502. [CrossRef]

12. Yang, Z.; Rao, F.; Zhu, P. The Impact of Specialized Agricultural Services on Land Scale Management: An Empirical Analysis from the Perspective of Farmers' Land Transfer-in. Chin. Rural Econ. 2019, 3, 82-95. (In Chinese)

13. Xie, Y.; Jiang, Q. Land arrangements for rural-urban migrant workers in China: Findings from Jiangsu Province. Land Use Policy 2016, 50, 262-267. [CrossRef]

14. Che, Y. Off-farm employments and land rental behavior: Evidence from rural China. China Agric. Econ. Rev. 2016, 8, 37-54. [CrossRef]

15. Han, X.; Zhang, N. Does the subsidy policy hinder the expansion of the planting scale of grain? J. Agrotech. Econ. 2020, 8, 29-39. (In Chinese) [CrossRef] 
16. Guo, S.; Li, C.; Wei, Y.; Zhou, K.; Liu, S.; Xu, D.; Li, Q. Impact of land expropriation on farmers' livelihoods in the mountainous and hilly regions of Sichuan, China. J. Mt. Sci. 2019, 16, 2484-2501. [CrossRef]

17. Zhang, Y.; Wang, Y.; Bai, Y. Knowing and Doing: The Perception of Subsidy Policy and Farmland Transfer. Sustainability 2019, 11, 2393. [CrossRef]

18. Zhang, Y.; Bai, Y.; Xin, L. Relationships between cultivated land quality and land transfer behaviors at the plot scale. Resour. Sci. 2019, 41, 1102-1110. [CrossRef]

19. Mehretie, B.; Assefa, A.; Woldeamlak, B. Livelihood options of landless households and land contracts in north-west Ethiopia. Environ. Dev. Sustain. 2017, 19, 141-164. [CrossRef]

20. Barbieri, A.F.; Pan, B.W.K. Farm household lifecycles and land use in the Ecuadorian Amazon. Popul. Environ. 2005, $27,1-27$. [CrossRef]

21. Paul, M.; Wa, G.M. Small farms, smaller plots: Land size, fragmentation, and productivity in Ethiopia. J. Peasant Stud. 2017, 45, 757-775. [CrossRef]

22. Min, S.; Waibel, H.; Huang, J. Smallholder participation in the land rental market in a mountainous region of Southern China: Impact of population aging, land tenure security and ethnicity. Land Use Policy 2017, 68, 625-637. [CrossRef]

23. Lyu, K.; Chen, K.; Zhang, H. Relationship between land tenure and soil quality: Evidence from China's soil fertility analysis. Land Use Policy 2019, 80, 345-361. [CrossRef]

24. Han, W.; Zhang, Z.; Zhang, X.; He, L. Farmland Rental Participation, Agricultural Productivity, and Household Income: Evidence from Rural China. Land 2021, 10, 899. [CrossRef]

25. Borchers, A.; Ifft, J.; Kuethe, T. Linking the price of agricultural land to use values and amenities. Am. J. Agric. Econ. 2014, 96, 1307-1320. [CrossRef]

26. Zhou, H.; Zhou, H. The Influence of Farmers' Social Trust on Land Transfer Rent-Empirical Analysis Based on CHIP Data. J. Public Manag. 2019, 16, 118-130. (In Chinese) [CrossRef]

27. Hayes, A.F.; Matthes, J. Computational procedures for probing interactions in OLS and logistic regression: SPSS and SAS implementations. Behav. Res. Methods 2009, 41, 924-936. [CrossRef] [PubMed]

28. Gan, L.; Yin, Z.; Tan, J. Report on the Development of Household Finance in Rural China (2014); Springer: Singapore, 2016. [CrossRef]

29. Matthew, D. Rethinking Land Endowment and Inequality in Rural Africa: The Importance of Soil Fertility. World Dev. 2016, 87, 258-273. [CrossRef]

30. Tittonell, P.; Muriuki, A.; Shepherd, K.D.; Mugendi, D.; Kaizzi, K.C.; Okeyo, J.; Verchot, L.; Coe, R.; Vanlauwe, B. The diversity of rural livelihoods and their influence on soil fertility in agricultural systems of East Africa-A typology of smallholder farms. Agric. Syst. 2010, 103, 83-97. [CrossRef]

31. Kleemann, J.; Baysal, G.; Bulley, H.N.N.; Fürst, C. Assessing driving forces of land use and land cover change by a mixed-method approach in north-eastern Ghana. J. Environ. Manag. 2017, 196, 411-442. [CrossRef] [PubMed]

32. Nguyen, A.T.; Hens, L. Diversified responses to contemporary pressures on sloping agricultural land: Thai farmer's perception of mountainous landscapes in northern Vietnam. Environ. Dev. Sustain. 2021, 23, 5429. [CrossRef]

33. Ericksen, P.; Ardón, M. Similarities and differences between farmer and scientist views on soil quality issues in central Honduras Geoderma 2003, 111, 233-248. [CrossRef]

34. Steenwerth, K.; Belina, K.M. Cover crops enhance soil organic matter, carbon dynamics and microbiological function in a vineyard agroecosystem. Appl. Soil Ecol. 2008, 40, 359-369. [CrossRef]

35. Dumanski, J.; Pieri, C. Land quality indicators: Research plan. Agric. Ecosyst. Environ. 2000, 81, 93-102. [CrossRef]

36. He, Q.; Deng, X.; Li, C.; Kong, F.; Qi, Y. Does Land Transfer Improve Farmers' Quality of Life? Evidence from Rural China. Land 2022, 11, 15. [CrossRef]

37. Ahmat, N.H.C.; Arendt, S.W.; Russell, D.W. Effects of minimum wage policy implementation: Compensation, work behaviors, and quality of life. Int. J. Hosp. Manag. 2019, 81, 229-238. [CrossRef]

38. Estes, R.J.; Sirgy, M.J. Global Advances in Quality of Life and Well-Being: Past, Present, and Future. Soc. Indic. Res. 2019, 141, 1137-1164. [CrossRef]

39. Yao, C.Y. Local versus global separability in agricultural household models: The factor price equalization effect of land transfer rights. Am. J. Agric. Econ. 2002, 84, 702-715. [CrossRef]

40. Wang, X.L.; Peng, L.; Xu, D.D.; Wang, X.X. Sensitivity of Rural Households' Livelihood Strategies to Livelihood Capital in Poor Mountainous Areas: An Empirical Analysis in the Upper Reaches of the Min River, China. Sustainability 2019, 11, 2193. [CrossRef]

41. Slavchevska, V. Gender differences in agricultural productivity: The case of Tanzania. Agric. Econ. 2015, 46, 335-355. [CrossRef]

42. Yan, Z.; Wei, F.; Deng, Z.; Li, C.; He, Q.; Qi, Y. Feminization of Agriculture: Do Female Farmers Have Higher Expectations for the Value of Their Farmland?-Empirical Evidence from China. Agriculture 2022, 12, 60. [CrossRef]

43. Guo, S.L.; Lin, L.; Wei, Y.L.; Xu, D.D.; Li, Q.Y.; Liu, S.Q. Interactions between Sustainable Livelihood of Farm household and Agricultural Land Transfer in the Mountainous and Hilly Regions of Sichuan, China. Sustain. Dev. 2019, 27, 725-742. [CrossRef]

44. Mullan, K.; Grosjean, P.; Kontoleon, A. Land Tenure Arrangements and Rural-Urban Migration in China. World Dev. 2011, 39, 123-133. [CrossRef]

45. $\mathrm{Hu}, \mathrm{F} . ; \mathrm{Xu}, \mathrm{Z}$.; Chen, Y. Circular migration, or permanent stay? Evidence from China's rural-urban migration. China Econ. Rev. 2011, 22, 64-74. [CrossRef] 
46. Huang, K.; Deng, X.; Liu, Y.; Yong, Z.; Xu, D. Does off-Farm Migration of Female Laborers Inhibit Land Transfer? Evidence from Sichuan Province, China. Land 2020, 9, 14. [CrossRef]

47. Hoq, M.S.; Raha, S.K.; Hossain, M.I. Livelihood vulnerability to flood hazard: Understanding from the flood-prone Haor Ecosystem of Bangladesh. Environ. Manag. 2021, 67, 532-552. [CrossRef]

48. Wang, J.; Xin, L.; Wang, Y. How farmers' non-agricultural employment affects rural land circulation in China? J. Geogr. Sci. 2020, 30, 378-400. [CrossRef]

49. Pfeiffer, L.; López-Feldman, A.; Taylor, J.E. Is off-farm income reforming the farm? Evidence from Mexico. Agric. Econ. 2009, 40, 125-138. [CrossRef]

50. Wang, Y.; Xin, L.; Zhang, H.; Li, Y. An Estimation of the Extent of Rent-Free Farmland Transfer and Its Driving Forces in Rural China: A Multilevel Logit Model Analysis. Sustainability 2019, 11, 3161. [CrossRef]

51. Du, J.; Zeng, M.; Xie, Z.; Wang, S. Power of Agricultural Credit in Farmland Abandonment: Evidence from Rural China. Land 2019, 8, 184. [CrossRef]

52. Cheng, H.; Zhang, Y. Impact of Professional Differentiation of Rural Women on Their Family's Willingness to Circulate Contracted Land: A Comparative Study on Female's Agricultural and Non-agricultural Employment. J. Nanjing Agric. Univ. 2014, 14, 57-65. (In Chinese)

53. Wineman, A.; Liverpool, L. Land Markets and Land Access Among Female-Headed Households in Northwestern Tanzania. World Dev. 2017, 100, 108-122. [CrossRef]

54. Burke, W.; Li, S.; Banda, D. Female access to fertile land and other inputs in Zambia: Why women get lower yields. Agric. Human Values 2018, 35, 761-775. [CrossRef] 